\title{
THE EFFECT OF PROFITABILITY AND LIQUIDITY TOWARDS THE CAPITAL STRUCTURE ON RETAIL COMPANIES THAT ARE LISTED IN INDONESIA STOCK EXCHANGE IN THE PERIOD OF 2014 - 2015
}

\author{
Vinny Stephanie Hidayat ${ }^{(1)}$ \\ Universitas Kristen Maranatha \\ vinny.tan@yahoo.co.id \\ Debbianita $^{(2)}$ \\ Universitas Kristen Maranatha \\ debbianita@gmail.com
}

\begin{abstract}
The aim of this research is to determine the effect of profitability and liquidity towards the capital structure on retail companies that are listed in Indonesia Stock Exchange. The population of this research is whole of the retail companies that are listed in the Indonesia Stock Exchange in 2014-2015. The method used in this research is explanatory research, and the sampling method used was judgement sampling method. Research hypothesis testing using T test, F test, and multiple regression analysis using SPSS version 20.0. The partially effect is shown by T test, except for profitability variable and the simultaneous effect is shown by $F$ Test. The result of this research shows that the profitability and liquidity affect the capital structure simultaneously. Thus, the hypothesis of the research is empirically supported.
\end{abstract}

\section{Keywords: Capital Structure, Profitability, Liquidity, and Retail Companies}

\section{INTRODUCTION}

\section{Background of The Study}

A company in running its business and venture needs funds. Funds can be obtained from the owner of the company or debt. Funds received by company are used to buy fixed assets in producing goods and services, to buy materials for the purpose of production and sales, to issue accounts receivable, and to provide cash supplies and buy securities that are often called stocks or securities for both transaction and maintaining company's liquidity (Krsitian \& Khuzaini, 2014).

According to Joni \& Lina (2010) in Yusrianti (2013), the source of funding obtained by a company may come from internal and external of the company. Funds obtained from the owner of the company are their own capital or come from the company's 
internal funds while the funds obtained from outside of the company, such as from creditors are debts for the company.

In developing a company, it needs capital in the form of cash in the company, if the company does not have enough cash, it will be difficult for the company to develop because of the small amount of cash so it is difficult to pay debts (Resino, Syafitri, \& Wijaya, 2015).

Capital structure is the composition of expenditure which usually refers to the proportion between long-term debts, preferred stock, and own capital which are presented in the company's balance sheet. Capital structure can also be interpreted as a balance or comparison between the amounts of long-term debt with own capital (Riyanto (2001) in Fibriyanto, Yaningwati, \& Za (2015)). Capital structure is affected by several factors, among them are profitability and liquidity.

The meaning of liquidity ratios according to Hanafi \& Halim (2005) in Krsitian \& Khuzaini (2014) is a ratio that measures a company's ability to fulfill its short-term obligations. The higher the liquidity ratio, the more likely the debt can be paid and vice versa. In order to grow and be able to pay off the company's debt, the company needs profit (Resino, Syafitri, \& Wijaya, 2015). Profit generated by the company can be used for the development of the company and settle the company's debt. The ability to generate profits is called the profitability ratio (Resino, Syafitri, \& Wijaya, 2015).

\section{LITERATURE REVIEW}

\section{Capital Structure}

Capital structure is the composition of expenditure which usually refers to the proportion between long-term debts, preferred stock, and own capital which are presented in the company's balance sheet. Capital structure can also be interpreted as a balance or a comparison between the amounts of long-term debt with own capital (Riyanto (2001) in Fibriyanto, Yaningwati, \& Za (2015)).

According to Megginson (1997) in Muhammad Edi Wijaya (2001) in Fadli (2010) the trade-off theory model assumes that the company's capital structure is the result of tradeoffs of tax profits by using debt with agency costs which will occur with the use of the debt. This model is a development of Modigliani Miller's theory of irrelevance capital structure hypothesis. Modigliani Miller argues that in perfect market conditions, the value of a company using debt will be the same as a company which does not use debt. But they revised the results of their study by saying that with tax, the debt would be relevant.

\section{Profitability}

Profitability is the company's ability to generate profits and operational efficiency as well as the efficiency of its use of assets (Chen (2004) in Bukit (2012)).The Pecking Order Theory (POT) explains why profitable companies generally borrow in small amounts. This is not because they have a low target of debt ratio, but it's because they require small amount of external financing (Husnan (2000) in Rahmayani (2008)). 
H1: Profitability affects the capital structure of retail companies which are listed on the Indonesia Stock Exchange in 2014-2015.

\section{Liquidity}

Liquidity is the ability of a company to fulfill its financial obligations in the short term or which are to be paid immediately. This tool for fulfilling short-term financial obligations comes from liquid asset elements, namely current assets with turnover of less than one year, because they are more easily to be disbursed / liquefied than fixed assets which has a turnover of more than one year (Harahap (2010) in Hakim (2013))

The calculation of this ratio is based on a simple comparison of total current assets and current liabilities. This current assets are the amount of liquid assets, for example cash available for business. While current liabilities provide an indication of the need for cash in the future (Ciaran Walsh (2003) in Hakim (2013)).

$\mathrm{H} 2$ : Liquidity affects the capital structure of retail companies which are listed on the Indonesia Stock Exchange in 2014-2015

\section{Hypothesis Development}

Profitability has a negative effect towards capital structure. According to Adrianto and Wibowo (2007), in Wijaya and Hadianto (2008) in Yusrianti (2013), they stated that in the Pecking Order Theory and the arguments of previous researchers, company that has a huge level of profit will have a larger internal funding source and encourage companies to use them especially to meet the needs of financing corporate investment so that the level of debt usage or external funding used is relatively small and will minimize the risk of bankruptcy and high debt costs. This is in a line with the research conducted by Resino, Syafitri, \& Wijaya (2015) who states that profitability has a negative effect towards capital structure. This is in accordance with the Pecking Order Theory which states that a company with a high level of profitability is actually low in debt, because company that has a high profitability has very good funding sources. However, this is opposite to the research conducted by Nugrahani \& Sampurno (2012) who stated that profitability does not affect the capital structure. This is caused by the essence of trade-offs or balancing theories which balance the benefits and sacrifices that emerged as a result of using debt. So the company does not regard the size of the amount of profit in determining its capital structure, but the amount of the sacrifices and the profits obtained by the company (Hidayati, 2009).

\section{RESEARCH METHOD}

\section{Type of Research}

The general purpose of this research is to explain and prove the independent effect of profitability and liquidity on the capital structure. Therefore, it can be concluded that this research is explanatory research. According to Umar (1999) in Wijaya (2013) explanatory research is a research that aims to analyze the relation between one variable and another variable or how a variable affects other variables. 


\section{Variable Operationalization}

Table 1

Variable Operationalization

\begin{tabular}{|c|c|c|c|c|}
\hline $\begin{array}{l}\mathrm{N} \\
0 \\
\end{array}$ & Vanable & Vanable & Indicator & Scale \\
\hline 1 & $\begin{array}{l}\text { Profitability } \\
\text { (ROA) } \\
\text { (X1) }\end{array}$ & $\begin{array}{l}\text { The company's ability to } \\
\text { generate profits and } \\
\text { operational efficiency as well } \\
\text { as the efficiency of the use of } \\
\text { assets (Chen (2004) in Bukit } \\
\text { (2012)) }\end{array}$ & ROA $=\frac{\text { Total EBIT }}{\text { Total Asset }} \times 100 \%$ & Ratio \\
\hline 2 & $\begin{array}{l}\text { Liquidity (CR) } \\
\text { (X2) }\end{array}$ & $\begin{array}{l}\text { Liquidity is the ability of a } \\
\text { companyto fulfillits financial } \\
\text { obligations in the short term or } \\
\text { which are to be paid } \\
\text { immediately (Harahag (2010) } \\
\text { in Hakim(2013)) }\end{array}$ & $\mathrm{CR}=\frac{\text { Current Assets }}{\text { Current tiabilities }}$ & Ratio \\
\hline 3 & $\begin{array}{c}\text { Capital Structure } \\
\text { (DER) } \\
\text { (I) }\end{array}$ & $\begin{array}{l}\text { The composition of } \\
\text { expenditure which usually } \\
\text { refers to the proportion } \\
\text { betweenlong-tem debts, } \\
\text { preferred stock, and own } \\
\text { capital which are presented in } \\
\text { the company's balance sheet. } \\
\text { Capital structure can also be } \\
\text { interpreted as a balance or a } \\
\text { companison between the } \\
\text { amounts oflong-tem debt } \\
\text { with own capital (Rixante } \\
\text { (2001)in Fibnixante, } \\
\text { Yaningyati, \& } \mathrm{Za} \text { (2015)). }\end{array}$ & DER $=\frac{\text { Total Liabilities }}{\text { Total Equity }} \times 100 \%$ & Ratio \\
\hline
\end{tabular}

\section{Population and Sample}

The populations used in this study were retail companies listed in the Indonesia Stock Exchange from 2014-2015. From the financial statements of companies listed in the Indonesia Stock Exchange, researchers will analyze the Capital Structure (DER), where this study will be conducted to examine whether the Capital Structure can be affected by Profitability (ROA) and Liquidity (CR). The researchers used 15 samples of companies in this study in a period of 2 years (2014-2015). The samples selection method used was purposive judgment sampling method. Purposive judgment sampling method is a method of selecting samples based on the criteria in the form of certain considerations (Hartono (2004) in
Meythi, En, \& Rusli (2011)). Data collection technique in this study is archival strategy, where to obtain secondary data in the form of financial statements of retail companies listed in the Indonesia Stock Exchange for the period of 2014-2015, the researcher had to collect data from the Indonesia Stock Exchange database (Hartono, 2012)

\section{Analysis Tool Descriptive Test}

Descriptive analysis describes a summary of research data such as the mean, standard deviation, variance, mode, etc., also performed measurements like skewness and kurtosis to describe whether or not the distribution of data is normal. In this discussion a descriptive analysis will be conducted by giving a description of data on the amount of data, minimum, maximum, mean, and standard deviation (Tiawan, 2011).

\section{Classic Assumption Test}

\section{Normality Test}

The normality test aims to test whether or not the regression model, the dependent and the independent variables both have normal distribution (Ghozali (2006) in Adhitama (2014). The normality test in this study was conducted using the Kolmogorovsmirnov test, the data is normally distributed if it has a test probability value greater than 0.05 (Ghozali (2006) in Adhitama (2014).

\section{Multicollinearity Test}

Multicollinearity means that one independent variable with the other 
independent variables in the regression model correlates to each other(Hasan (1999) in Meythi, En, \& Rusli (2011)). Ghozali (2006) in Meythi, En, \& Rusli (2011) revealed that the way to find out about multicollinearity is that if the variance inflation factor's (VIF) value is greater than 10 and the tolerance value is below 0.1 , multicollinearity is said to have occurred. Multicollinearity testing was conducted using the SPSS 12.0 program for Windows by activating the choice of Covariance Matrix and Collinearity Diagnostics (Ghozali, (2006) in Meythi, En, \& Rusli (2011)).

\section{Autocorrelation Test}

The autocorrelation test aims to test whether in the linear regression model there is a correlation between the confounding errors in period $t$ and the confounding errors in the $\mathrm{t}-1$ period (previous)

Basic decision making:

1. If $\mathrm{d}$ is smaller than $\mathrm{dL}$ or greater than (4-dL), the hypothesis 0 is rejected, which means there is autocorrelation.

2. If $d$ is located between dU and (4$\mathrm{dU})$, then the hypothesis 0 is accepted, which means there is no autocorrelation.

3. If $\mathrm{d}$ is located between $\mathrm{dL}$ and $\mathrm{dU}$ or between (4-dU) and (4-dL), then there is no definite conclusion (Raharjo, 2014).

\section{Heteroscedasticity Test}

If the variation of the confounding factors from the data is always the same on one observation data to another observation data, then the variation is homoschedastic. If this assumption is not fulfilled, it can be said to have deviations called heteroscedasticity (Firdaus (2004) in Meythi, En, \& Rusli (2011)). The researchers used the Glejser Test to test heteroscedasticity in this study. According to Ghozali (2006) in Meythi, En, \& Rusli (2011) if the effect of independent variables on absolute regression values is significant (below the significance level or $\alpha$, then there is heteroscedasticity. The level of significance $(\alpha)$ which was applied to SPSS is $5 \%$, then the basis of decision making are:

1. If the value in the Sig / Significance column (in the output Coefficients) is> $5 \%$, there is no heteroscedasticity.

2. If the value in the Sig / Significance column (in the output Coefficients)is $<5 \%$, there is heteroscedasticity occurred.

\section{Hypothesis Test Partial Significance Test (T-Test)}

To prove whether liquidity and profitability effects the stock prices partially and to test the interaction between liquidity and profitability on stock prices, a t-test is conducted. The statistical test $\mathrm{t}$ (t-test) basically shows how far the effect of an explanatory / independent variable individually in explaining the variation of the dependent variable (Ghozali (2006) in Meythi, En, \& Rusli (2011)). The SPSS 12.0 program was used for this test. The level of significance applied to SPSS was $5 \%$. The basis or benchmark in decision making are (Santoso (2000) in Meythi, En, \& Rusli (2011)):

1. If the significance value of t-counts (Sig / Significance value at output 
Coefficient) is $>0.05$ then $\mathrm{Ho}$ is accepted and $\mathrm{Ha}$ is rejected.

2 . If the significance value of $t$-counts (Sig / Significance value at output Coefficient) is $<0.05$ then $\mathrm{Ho}$ is rejected and $\mathrm{Ha}$ is accepted.

\section{Simultaneous Significance Test (F- Test)}

Simultaneous test or also called the F test, in multiple linear regression analysis aims to determine whether or not the independent variable (X) together or simultaneously (simultaneous) affect the dependent variable (Y). Basis of Decision Making For F Test (Simultaneous) In Regression Analysis

1. Based on the calculated $F$ value and F table:

If the value of the F count is $>\mathrm{F}$ table, the independent variable $(\mathrm{X})$ affects the dependent variable (Y) .If the value of the $\mathrm{F}$ count is $<\mathrm{F}$ table, the independent variable $(\mathrm{X})$ does not affect the dependent variable (Y).

2. Based on the significance value of the SPSS output:

If the value is Sig. $<0.05$, the independent variable (X) has a significant effect on the dependent variable (Y). If the value is Sig. > 0.05, the independent variable $(\mathrm{X})$ does not have a significant effect on the dependent variable (Y) (Priady, 2015).

\section{Research Results and Discussion}

\section{Descriptive Test}

Table 2

Descriptive Test Result

\begin{tabular}{|l|r|r|r|r|r|}
\hline & N & Minimum & Maximmm & Mean & $\begin{array}{c}\text { Std. } \\
\text { Deviation }\end{array}$ \\
\hline ROA & & & & & 15.47689 \\
CR & 30 & .01 & 68.00 & 10.0907 & 2.36498 \\
DER & 30 & .01 & 9.04 & 2.6657 & 2.13929 \\
ValidN & 30 & .18 & 93.60 & 12.2223 & 26.1392 \\
(listwise) & 30 & & & & \\
\hline
\end{tabular}

Based on table 5, the ROA variable has a mean (average) of 10.0907 with a standard deviation of 15.47689 , the greatest value is 68.00 and the smallest value is 0.01 .

The $\mathrm{CR}$ variable has a mean (average) of 2.6657 with a standard deviation of 2.36498, the greatest value is 9.04 and the smallest value is 0.01 .

The DER variable has a mean (average) of 12.2223 with a standard deviation of 26.13929, the greatest value is 93.60 and the smallest value is 0.18 .

\section{Classic Assumption Test Normality Test}

Table 3

Normality Test Results One-Sample Kolmogoroy-Smirnov Test

\begin{tabular}{|c|c|c|}
\hline & & $\begin{array}{c}\text { Unstandardize } \\
\text { d Residual }\end{array}$ \\
\hline \multicolumn{2}{|l|}{$\mathrm{N}$} & $\begin{array}{r}30 \\
0 \mathrm{E}-7\end{array}$ \\
\hline Normal Parameters & $\begin{array}{l}\text { Std. } \\
\text { Deviation }\end{array}$ & .70164118 \\
\hline Most Extreme & Absolute & .191 \\
\hline Differences & $\begin{array}{l}\text { Positive } \\
\text { Negative }\end{array}$ & $\begin{array}{r}.191 \\
-105\end{array}$ \\
\hline Kolmogorox-Smimov Z & & 1.047 \\
\hline Asymp. Sig. (2-tailed) & & .223 \\
\hline
\end{tabular}

Interpretation of the test results (seen from the sig value), the data has a normal distribution, because all the 
variables have a sig value above 0.05 , where the sig value is 0.223 .

Multicollienarity Test

Table 4

Multicollinearity Test Result

\begin{tabular}{|l|l|l|}
\hline \multicolumn{3}{|l|}{ Collinearity Statistics } \\
\hline Model & Tolerance & VIF \\
\hline ROA & .924 & 1.802 \\
\hline CR & .924 & 1.802 \\
\hline
\end{tabular}

All independent variables are free from multicollinearity because all independent variables have a tolerance value above 0.1 and VIF below 10 , where the ROA tolerance value is 0.924 and the tolerance value of $\mathrm{CR}$ is 0.924 . While the value of VIF ROA is 1.802 and the Value of VIF CR is 1.802 .

\section{Autocorrelation Test}

Table 5

Autocorrelation Test Result Model Summary

\begin{tabular}{|c|c|c|c|c|c|}
\hline Model & $\bar{R}$ & R Square & $\begin{array}{c}\text { Adjusted R } \\
\text { Square }\end{array}$ & $\begin{array}{l}\text { Std. Error of } \\
\text { the Estimate }\end{array}$ & $\begin{array}{l}\text { Durbin- } \\
\text { Watson }\end{array}$ \\
\hline 1 & $.452^{\circ}$ & .204 & .145 & .72716 & 2.269 \\
\hline
\end{tabular}

With the value of $\mathrm{n}=30 \mathrm{du}$ value is 1.5666, and a value of 4-du $=4-1.5666$ $=2.4334$, it can be concluded that the model is not subjected to autocorrelation, because the DurbinWatson value is 2.269 , which means that it is between the values of 1.5666 and 2,4334.

\section{Heteroscedasticity Test}

Table 6

Heteroscedasticity Test Result

\begin{tabular}{|c|c|}
\hline Model & Sig \\
\hline ROA & .649 \\
\hline CR & .894 \\
\hline
\end{tabular}

With the sig ROA value of 0.649 , the sig CR value is 0.894 , and it can be concluded that there is no heteroscedasticity because all variables have sig values above 0.05 .

\section{Research Results \\ Partial Significance Test (T-Test)}

Table 7

T-test Table

\begin{tabular}{|c|c|c|}
\hline \multicolumn{3}{|c|}{ Collinearity Statistics } \\
\hline Model & T & sig \\
\hline (Constant) & 3.395 & .002 \\
\hline ROA & -.857 & .399 \\
\hline CR & -2.628 & .014 \\
\hline
\end{tabular}

The Effect of ROA towards Capital Structure

Based on the calculation result using SPSS, a t value of -0.857 is obtained, with a sig value of 0.399 , where the sig value is greater than 0.05 . So that it can be concluded, that the independent variable ROA, partially, has no significant effect towards the dependent variable (Capital Structure).

\section{The Effect of CR towards Capital Structure}

Based on the calculations result using SPSS, a t value of $-2,628$ is obtained, with a sig value of 0.014 , where the sig value is smaller than 0.05 . So it can be 
concluded, that the independent variable $\mathrm{CR}$, partially, has a negative and significant effect towards the dependent variable (Capital Structure).

\section{Simultaneous Significance Test (F- Test)}

Table 8

\section{F-Test Result}

\begin{tabular}{|c|c|c|c|c|c|c|}
\hline \multicolumn{7}{|c|}{ ANOYA } \\
\hline$\overline{\mathrm{Mo}}$ & & $\begin{array}{l}\text { Sum of } \\
\text { Squares }\end{array}$ & df & Mean Square & $\mathrm{F}$ & Sig. \\
\hline \multirow{3}{*}{1} & $\begin{array}{l}\text { Regression } \\
\end{array}$ & 3.661 & 2 & 1.830 & 3.462 & $.046^{\mathrm{b}}$ \\
\hline & Residual & 14.277 & 27 & .529 & & \\
\hline & Total & 17.938 & 29 & & & \\
\hline
\end{tabular}

Based on the calculation result using SPSS, an F value of 3.462 is obtained, with a sig value of 0.046 , where the sig value is smaller than 0.05 . So, it can be concluded that the independent variables (ROA and $\mathrm{CR}$ ), simultaneously affecting the dependent variable (Capital Structure).

\section{Research Result Discussion}

The effect of Return On Assets (ROA) towards Capital Structure

ROA does not affect the Capital Structure. This is in accordance with the research result conducted by Nugrahani \& Sampurno (2012) who stated that profitability does not affect the capital structure. This is caused by the essence of trade-offs or balancing theories that balance out the benefits and sacrifices that appeared as a result of using debt. So that the company does not see the small size of the amount of profit in determining the capital structure, but the the size of the sacrifices and the profits obtained by the company (Hidayanti, 2009).
The Effect of Current Ratio towards Capital Structure

CR affects the Capital Structure. This is in accordance with the results of a research conducted by Hakim (2013) who stated that in accordance with the Pecking Order Theory, companies that have a high level of profitability and liquidity are actually in low debt levels, so the company does not use debt financing. This is because companies have abundant internal funding sources, so companies are more likely to use their internal funds to finance their investments before using external financing through debt.

\section{CONCLUSIONS SUGGESTIONS}

AND

\section{Conclusion}

Based on the results of research that has been done, conclusions can be obtained as follows:

1. Profitability does not affect the Capital Structure of Retail companies listed in the Indonesia Stock Exchange in 2014-2015.

2. Liquidity affects the Capital Structure of Retail companies listed in the Indonesia Stock Exchange in 20142015.

3. Profitability and Liquidity affect the Capital Structure of Retail companies listed in the Indonesia Stock Exchange in 2014-2015.

\section{Suggestions}

\section{Suggestions for Retail Company}

Retail companies should conduct a more in-depth analysis of the exact comparison between debt and equity in their capital structure, so as to get the benefits of using debt optimally. 
Suggestions for Next Accounting Researcher

1. The sample used in this study are only the companies in the retail subsector, then in the next study it is recommended to expand the scope of research to other sectors and subsector companies.

2. This research only examines the state of the company in a span of 2 years (2014-2015), so that further researchers can increase the time span of the study so that the results are more accurate and representative.

3. The independent variables used in this study are only limited to profitability (ROA), and Current Ratio (CR), so it is suggested to future researchers to add other variables as predictors in predicting capital structure.

\section{BIBLIOGRAPHY/REFERENCES}

\section{Book}

Hanafi, Mamduh M., \& Halim, Abdul. (2005). Analisis Laporan Keuangan. Edisi Dua.Yogyakata: UPP AMP YPKN.

Hartono, Jogiyanto. (2012). Metodologi Penelitian Bisnis Salah Kaprah dan Pengalaman - pengalaman. Yogyakarta: BPFE.

Sartono, Agus. (2001). Manajemen Keuangan Teori Dan Aplikasi. Edisi Empat. Yogyakarta:BPFE.

\section{Journal}

Adhitama, Paulus Patria. 2014.

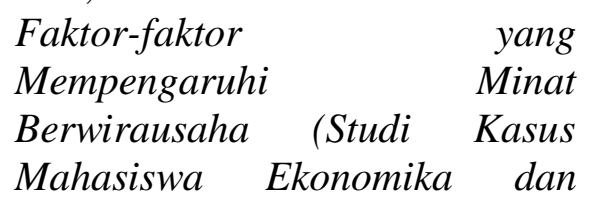

Bisnis UNDIP,Semarang). Skripsi, Semarang: Program Studi S-1 Fakultas Ekonomi Universitas Diponegoro.

Bukit, Rina Br. 2012.Pengaruh Struktur Modal terhadap Nilai Perusahaan Melalui Profitabilitas: Analisis Data Panel Manufaktur di Bursa Efek Indonesia. Jurnal Keuangan dan Bisnis. Vol. 4 (No.3), hal. 203-208.

Fadli. 2010. Analisis Pengaruh Faktor-faktor Penentu Kebijakan Struktur Modal Terhadap Leverage Hipotesis Pecking Order dan Trade Off Theory. Skripsi, Jakarta: Program Studi S-1 Manajemen Universitas Islam Negeri Syarif Hidayatullah. Fibriyanto, Danang, Yaningwati, Fransisca, \& Zahroh Za. 2015.Analisis Pengaruh Struktur Modal terhadap Nilai Perusahaan Properti dan Real Estate yang Listing di Bursa Efek Indonesia Tahun 20092011. Jurnal Administrasi Bisnis (JAB). Vol. 27 (No.2), hal. 1-8. Hakim, Arief Rahman. 2013. Pengaruh Struktur Aktiva, Profitabilitas, Ukuran Perusahaan, dan Likuiditas terhadap Struktur Modal (Studi Kasus pada Perusahaan Makanan dan Minuman yang Terdaftar di Bursa Efek Indonesia Tahun 2007-2012). Skripsi, Jakarta: Program Studi S-1 Manajemen Universitas Islam Negeri Syarif Hidayatullah. Hidayati, Nuril. 2009. Pengaruh Struktur Kepemilikan, Profitabilitas, Ukuran

Perusahaan, Pertumbuhan Aktiva, dan Risiko Bisnis 
terhadap Struktur Modal Studi pada Perusahaan yang Masuk Kelompok Jakarta islamix Index Tahun 2005-2007. Skripsi, Yogyakarta: Program Studi Keuangan Islam Jurusan Muamalah Fakultas Syariah Universitas Islam Negeri Sunan Kalijaga.

Krsitian, Nantyo dan

Khuzaini. 2014.Pengaruh

Likuiditas dan Profitabilitas terhadap Struktur Modal dan Rasio Aktivitas sebagai Intervening. Jurnal Ilmu \& Riset Manajemen. Vol. 3 (No.12) hal. 1-23.

Meythi, En, Tan Kwang, \& Rusli. 2011.Pengaruh Likuiditas dan Profitabilitas Terhadap Harga Saham Perusahaan Manufaktur yang Terdaftar di Bursa Efek Indonesia. Jurnal Bisnis Manajemen dan Ekonomi. Vol. 10 (No.2), hal. 2671-2684.

Nugrahani, Sarsa Meta dan Sampurno,

R. Djoko. 2012.Analisis Pengaruh Profitabilitas, Likuiditas, Pertumbuhan Penjualan, Ukuran Perusahaan, dan Kepemilikan Manajerial terhadap Struktur Modal (pada Perusahaan Manufaktur yang Terdaftar di Bursa Efek Indonesia periode 20082010) . Diponegoro Business Review. Vol. 1 (No.1), hal 1-9.

Rahmayani, Hanindita Noor. 2008. Pengaruh Kepemilikan Institusional dan Karakteristik Keuangan terhadap Keputusan Pendanaan (Studi Empiris pada Sektor Properti dan Real Estate di BEI Tahun 2001-2007). Thesis, Semarang: Program Studi S-2
Magister Manajemen Universitas Diponegoro.

Resino, Merdianti, Syafitri, Yancik, \& Wijaya, 2015. Pengaruh Likuiditas, Profitabilitas, Ukuran Perusahaan, dan Pertumbuhan Penjualan terhadap Struktur Modal. Jurnal, Palembang: Program Studi S1-Manajemen, STIE MDP.

Seftianne dan Handayani, Ratih. 2011.Faktor-Faktor yang Mempengaruhi Struktur Modal pada Perusahaan Publik Sektor Manufaktur. Jurnal Bisnis dan Akuntansi. Vol. 13 (No.1), hal. 39-56.

Yusrianti, Hasni. 2013. Pengaruh Tingkat Profitabilitas, Struktur Aset, dan Growth Opportunity terhadap Struktur Modal pada Perusahaan Manufaktur yang Telah Go Public di Bursa Efek Indonesia . Laporan Penelitian Dana Fakultas Ekonomi Unsri.

Internet

Priady, Wahyu. (2015). Uji Hipotesis: Uji Simultan atau Uji F Dengan Menggunakan SPSS 20. Diakses pada 01 Juni, 2016, dari http://jempolbayek.blogspot.co.id /2015/11/uji-hipotesis-ujisimultan-atau-uji-f.html

Raharjo, Sahid. (2014). Tutorial Uji Korelasi dengan Durbin Watson SPSS. Diakses pada 16 Mei, 2016, dari http://www.spssindonesia.com/2 014/02/uji-autokorelasi-dengandurbin-watson.html

Tiawan, Agus. (2011). Analisis Deskriptif. Diakses pada 16 Mei, 
2016, dari http://agustiawan99spss.blogspot.co.id/

Saham Ok. (2016). Sub Sektor Perdagangan Eceran BEI. Diakses pada 16 Mei, 2016, dari http://www.sahamok.com/emiten /sektor-perdagangan-jasainvestasi/sub-sektorperdagangan-eceran/

Wijaya, Wira. (2013). Penelitian Eksplanatori. Diakses pada 01 Juni, 2016, darihttp://kutukuliah.blogspot.co. id/2013/05/pengertianpenelitian-eksplanatoriadalah.html 